\title{
MODELLING OF MECHANICAL SYSTEMS BASING ON INTERCONNECTED DIFFERENTIAL AND PARTIAL DIFFERENTIAL EQUATIONS
}

\author{
A.D. Mizhidon, East Siberia State University of Technology and Management, \\ Ulan-Ude, Russian Federation, miarsdu@mail.ru
}

\begin{abstract}
The paper considers a boundary-value problem for a hybrid system of differential equations, which represents a generalized mathematical model for a system of interconnected rigid bodies attached to the rod by elastic-damping links. A hybrid system of differential equations is understood as a system of differential equations composed of ordinary differential equations and partial differential equations. For the theoretical foundations of our approach to investigation of the boundary value problem for the hybrid system of differential equations we propose a method of finding eigenvalues for the boundaryvalue problem. The comparative analysis of the results of numerical computations conducted with the use of the proposed method and the results obtained by other techniques known from the literature have proved the validity and the universal character of the proposed approach.
\end{abstract}

Keywords: boundary value problem; hybrid system of differential equations; eigenvalues.

\section{Introduction}

In the process of investigation of mechanical system containing both the objects with concentrated parameters and the objects with distributed parameters within the frames of existing theories the researches encounter substantial difficulties. The point is that, on the one hand, the respective theories for such objects have initially been represented in terms of different and sometimes hardly ever compatible languages. On the other hand, application of the Hamilton variation principle for constructing the equation of total dynamics for the systems with concentrated and distributed parameters necessitates consideration of hybrid systems of differential equations, whose investigation still needs due attention. The term "a hybrid system of differential equations" implies a system of differential equations composed of ordinary differential equations and partial differential equations.

As far as investigations of mechanical vibrations of elements of different constructions, parts and mechanisms are concerned, the computational schemes to be investigated are in many cases represented by rigid bodies (or systems of rigid bodies) interconnected with the aid of elastic links and the rod.

The issues of investigation of the systems of interconnected rigid bodies and elastic rods are discussed in [1-18]. The investigations bound up with mechanical systems and implying the application of various computational schemes (a rigid body linked with a rod; a cascade system of rigid bodies, which is connected with a rod; rigid bodies horizontally mounted (fixed) on a rod; several rigid bodies connected with each other and mounted on a rod) can be found in [1-6].

A generalized mathematical model of a system of rigid bodies mounted on the Euler Bernoulli beam, on whose basis a universal method of constructing a frequency equation for a given class of mechanical systems has been developed, can be found in [7]. An approach, which allows one to take into account the damping properties of elastic links in 
the generalized mathematical model, is described in [8]. Mathematical models of various typical computational schemes designed for a beam with rigid bodies elastically mounted on it and intended for investigation of free vibrations can be found in [9-18]. It is known that special analytical and numerical-analytical methods are developed for the purpose of investigations related to free vibrations. The method of finite elements can also be used in this case. Unfortunately, the majority of mathematical models of typical computational schemes are the models elaborated for particular case studies. Meanwhile, a generalized mathematical model [7] is needed.

The present paper considers a boundary value problem for a hybrid system of differential equations, which represents a generalized mathematical model of a system of interconnected rigid bodies, which are mounted on a rod by flexible-damping links.

\section{Problem Statement}

The accounting of damping in flexible links of the generalized mathematical model [7] leads to the general mathematical model suitable for a class of mechanical systems, which may be modelled as an Euler - Bernoulli beam with fixed edges and a system of rigid bodies mounted on the beam by elastic-damping links. Such a system of rigid bodies is described by the following hybrid system of differential equations [8]

$$
\left\{\begin{array}{l}
A \ddot{z}+C_{1} z+C_{2}(D z-\bar{u})+B_{1} \dot{z}+B_{2}(D \dot{z}-\dot{\bar{u}})=0, \\
k \frac{\partial^{2} u}{\partial t^{2}}(x, t)+b \frac{\partial^{4} u}{\partial x^{4}}(x, t)= \\
=\sum_{i=1}^{m}\left(q_{i}\left(d^{i T} z(t)-u(x, t)\right)+p_{i}\left(d^{i T} \dot{z}-\frac{\partial u}{\partial t}(x, t)\right)\right) \delta\left(x-a_{i}\right),
\end{array}\right.
$$

where $z(t)$ is an $n$-dimensional vector function; $u(x, t)$ is a scalar function; $\bar{u}(t)$ is an $m$ dimensional vector function with the components $u\left(a_{1}, t\right), \ldots, u\left(a_{m}, t\right) ; A, B_{1}, C_{1}$ are the given constant $n \times n$-matrices; $B_{2}, C_{2}$ are given constant $n \times m$-matrices; $D$ is a given constant $m \times n$-matrix; $d^{i}$ is an $n$-dimensional vector composed of the $i$-th row of matrix $D ; k, b, a_{i}, q_{i}, p_{i} ;(i=1, \ldots, m)$ are given constants, furthermore, $0 \leq a_{i} \leq l$; from now on, $(\cdot)^{T}$ denotes the transposition operation.

If we assume that function $u(x, t)$ in (1) describes transversal transitions of the rod's points, then, correspondingly, some boundary conditions, which correspond to some techniques of fixing the ends, have to be imposed on function $u(x, t)$.

In particular, in the case of stiff attaching (staying) at the rod's ends we have

$$
u(0, t)=u(l, t)=0, \quad \frac{\partial u}{\partial x}(0, t)=\frac{\partial u}{\partial x}(l, t)=0,
$$

in the case of stiff attaching (staying) at the left end and hinge-based attaching at the right end we have

$$
u(0, t)=0, \quad \frac{\partial u}{\partial x}(0, t)=0, \quad u(l, t)=0, \quad \frac{\partial^{2} u}{\partial x^{2}}(l, t)=0,
$$

in the case of stiff attaching on the left end and on the free right end we have

$$
u(0, t)=0, \quad \frac{\partial u}{\partial x}(0, t)=0, \quad \frac{\partial^{2} u}{\partial x^{2}}(l, t)=0, \quad \frac{\partial^{3} u}{\partial x^{3}}(l, t)=0 .
$$


Solution of the hybrid system of differential equations (1) is understood in the generalized sense. In this connection, let us introduce the concept of a generalized solution of the hybrid system of differential equations (1) satisfying some boundary conditions.

To this end let us consider a set of vector functions

$$
K=\left\{(y(\cdot), \nu(\cdot, \cdot))^{T}: y(\cdot) \in C_{\infty,[0, T]}^{n}, \nu(\cdot, \cdot) \in C_{\infty, \infty, D}\right\}
$$

where $D=\left\{(x, t) \in R^{2}: 0 \leq x \leq l, 0 \leq t \leq T\right\}$ is a rectangle. Let us call vector functions from the set $(5)$ the principal vector functions.

Noteworthy, in the case, when considering a boundary value problem for a mechanical system, which represents an Euler - Bernoulli beam with fixed ends and with a system of rigid bodies mounted on the beam by means of elastic-damping links, these bodies being interconnected via elastic-damping links, the class of principal functions may be interpreted as admissible variations of the generalized coordinates in the Hamilton principle.

Definition 1. A vector function $z(\cdot) \in C_{2,[0, T]}^{n}$, a scalar function $u(\cdot, \cdot) \in C_{4,2, D}$ represent the generalized solution of the boundary value problem for the hybrid system of differential equations (1), when (i) function $u(x, t)$ satisfies the boundary conditions of the boundaryvalue problem and (ii) for any principal vector function $(y(\cdot), \nu(\cdot, \cdot))^{T} \in K$ the following identity holds:

$$
\begin{aligned}
& \int_{0}^{T}\left(A \ddot{z}+C_{1} z+C_{2}(D z-\bar{u})+B_{1} \dot{z}+B_{2}(D \dot{z}-\dot{\bar{u}}), y(t)\right) d t+ \\
& +\iint_{D}\left(k \frac{\partial^{2} u}{\partial t^{2}}(x, t)+b \frac{\partial^{4} u}{\partial x^{4}}(x, t)-\sum_{i=1}^{m}\left(q_{i}\left(d^{i T} z(t)-u(x, t)\right)+\right.\right. \\
& \left.\left.+p_{i}\left(d^{i T} \dot{z}-\frac{\partial u}{\partial t}(x, t)\right)\right) \delta\left(x-a_{i}\right)\right) \cdot \nu(x, t) d x d t=0 .
\end{aligned}
$$

Let us consider a boundary value problem with the boundary conditions (2) or (3) or (4) for the system described by a hybrid system of differential equations (1).

\section{An Auxiliary Boundary Value Problem}

Having substituted functions $z(t), u(x, t)$ of the form

$$
z(t)=Z e^{\lambda t}, \quad u(x, t)=V(x) e^{\lambda t}
$$

into system (1), we have

$$
\begin{gathered}
\left(\lambda^{2} A+C_{1}+C_{2} D+\lambda\left(B_{1}+B_{2} D\right) Z-\left(C_{2}+\lambda B_{2}\right) \bar{V}=0,\right. \\
\lambda^{2} k V(x)+b \frac{d^{4} V(x)}{d x^{4}}=\sum_{i=1}^{m}\left(q_{i}\left(d^{i T} Z-V(x)\right)+\lambda p_{i}\left(d^{i T} Z-V(x)\right)\right) \delta\left(x-a_{i}\right),
\end{gathered}
$$

where $\bar{V}$ is an $m$-dimensional vector with the components $V\left(a_{1}\right), \ldots, V\left(a_{m}\right)$. 
Real or complex values of $\lambda$, for which there exists a generalized solution of the boundary value problem (4), (5), are hence called the eigenvalues. And the solutions of the boundary value problem corresponding to the eigenvalues ( $Z$ is an $n$-dimensional vector, $V(x)$ is a function) are called the eigen-solutions of this boundary-value problem.

Due to the boundary conditions imposed on function $u(x, t)$ function $V(x)$ satisfies the following conditions:

- under boundary conditions (2)

$$
V(0)=V(l)=0, \quad \frac{d V}{d x}(0)=\frac{d V}{d x}(l)=0,
$$

- under boundary conditions (3)

$$
V(0)=0, \quad \frac{d V}{d x}(0)=0, \quad V(l)=0, \quad \frac{d^{2} V}{d x^{2}}(l)=0,
$$

- under boundary conditions (4)

$$
V(0)=0, \quad \frac{d V}{d x}(0)=0, \quad \frac{d^{2} V}{d x^{2}}(l)=0, \quad \frac{d^{3} V}{d x^{3}}(l)=0 .
$$

Consider an auxiliary boundary value problem for the algebraic-differential system (6) - (7) with one of the boundary conditions (8), (9) or (10).

Definition 2. A function $V(\cdot) \in C_{4,[0, T]}$ and a vector $Z \in R^{n}$ are called a generalized solution of the auxiliary boundary value problem, when they satisfy the system of algebraic equations (6), the function $V(x)$ satisfies the given boundary condition, and for any component $v(\cdot, \cdot)$ of the principal vector function $(y(\cdot), v(\cdot, \cdot))^{T} \in K$, for any $t \in[0, T]$ the following identity holds:

$$
\begin{aligned}
& \int_{0}^{l}\left(\lambda^{2} k V(x)+b \frac{d^{4} V(x)}{d x^{4}}-\sum_{i=1}^{m}\left(q_{i}\left(d^{i T} Z-V(x)\right)+\right.\right. \\
& \left.\left.\quad+\lambda p_{i}\left(d^{i T} Z-V(x)\right)\right) \delta\left(x-a_{i}\right)\right) \cdot \nu(x, t) d x=0 .
\end{aligned}
$$

Theorem 1. The following representation is valid for any values of $\lambda$ and $Z$ in the generalized solution $V(x)$ of $(7)$

$$
V(x)=\sum_{i=1}^{m} G_{i}\left(x-a_{i}\right)\left(q_{i}\left(d^{i T} Z-V\left(a_{i}\right)\right)+\lambda p_{i}\left(d^{i T} Z-V\left(a_{i}\right)\right)\right),
$$

where functions $G_{i}(x),(i=1, \ldots, m)$ are the generalized solutions of the following equation

$$
\lambda^{2} k G_{i}(x)+b \frac{d^{4} G_{i}(x)}{d x^{4}}=\delta(x), \quad(i=1, \ldots, m) .
$$

Proof. Note, if function $V(x)$ is a generalized solution of (7), then the following identity is valid for any component $v(\cdot, \cdot)$ of the principal vector function $(y(\cdot), v(\cdot, \cdot)) \in K$, for 
any $t \in[0, T]$

$$
\begin{aligned}
\int_{0}^{l}\left(\lambda^{2} k V(x)+b \frac{d^{4} V(x)}{d x^{4}}\right) & \nu(x, t) d x= \\
& =\sum_{i=1}^{n}\left[\left(q_{i}\left(d^{i T} Z-V\left(a_{i}\right)\right)+\lambda p_{i}\left(d^{i T} Z-V\left(a_{i}\right)\right)\right) \nu\left(a_{i}, t\right)\right] .
\end{aligned}
$$

One can make sure that representation (11) is valid for the generalized solution of (7) by a direct substitution of (11) into the left-hand side of equation (13). To this end, let us represent equation (11) in the form

$$
V(x)=\sum_{i=1}^{m} \int_{0}^{l} G_{i}(x-\xi)\left(q_{i}\left(d^{i T} Z-V(\xi)\right)+\lambda p_{i}\left(d^{i T} Z-V(\xi)\right)\right) \cdot \delta\left(\xi-a_{i}\right) d \xi .
$$

Substitute (14) into the left-hand side of equation (13). Next, by changing the order of integration and taking into account relationship (12), we obtain the following:

$$
\begin{aligned}
& \int_{0}^{l}\left\{\int _ { 0 } ^ { l } \sum _ { i = 1 } ^ { m } \left[( k \lambda ^ { 2 } G _ { i } ( x - \xi ) + b \frac { d ^ { 4 } G _ { i } ( x - \xi ) } { d x ^ { 4 } } ) \left(q_{i}\left(d^{i T} Z-V(\xi)\right)+\right.\right.\right. \\
& \left.\left.\left.+\lambda p_{i}\left(d^{i T} Z-V(\xi)\right)\right) \delta\left(\xi-a_{i}\right)\right] d \xi\right\} \cdot \nu(x, t) d x= \\
& =\sum_{i=1}^{m} \int_{0}^{l}\left[( q _ { i } ( d ^ { i T } Z - V ( \xi ) ) + \lambda p _ { i } ( d ^ { i T } Z - V ( \xi ) ) ) \delta ( \xi - a _ { i } ) \cdot \int _ { 0 } ^ { l } \left(k \lambda^{2} G_{i}(x-\xi)+\right.\right. \\
& \left.\left.+b \frac{d^{4} G_{i}(x-\xi)}{d x^{4}}\right) \nu(x, t) d x\right] d \xi=\sum_{i=1}^{m} \int_{0}^{l}\left[\left(q_{i}\left(d^{i T} Z-V(\xi)\right)+\right.\right. \\
& \left.\left.+\lambda p_{i}\left(d^{i T} Z-V(\xi)\right)\right) \delta\left(\xi-a_{i}\right) \cdot \int_{0}^{l} \nu(x, t) \delta(x-\xi) d x\right] d \xi= \\
& =\sum_{i=1}^{m} \int_{0}^{l}\left[\left(q_{i}\left(d^{i T} Z-V(\xi)\right)+\lambda p_{i}\left(d^{i T} Z-V(\xi)\right)\right) \nu(\xi, t) \delta\left(\xi-a_{i}\right)\right] d \xi= \\
& =\sum_{i=1}^{n}\left[\left(q_{i}\left(d^{i T} Z-V\left(a_{i}\right)\right)+\lambda p_{i}\left(d^{i T} Z-V\left(a_{i}\right)\right)\right) \nu\left(a_{i}, t\right)\right] \text {, }
\end{aligned}
$$

what coincides with the right-hand side of (13).

Therefore, representation (11) is valid for the generalized solution $V(x)$ of $(7)$. 
Corollary 1. If generalized solutions $G_{i}(x),(i=1, \ldots, m)$ of (12) satisfy the following boundary conditions

$$
G_{i}\left(-a_{i}\right)=G_{i}\left(l-a_{i}\right)=0, \quad \frac{d G_{i}}{d x}\left(-a_{i}\right)=\frac{d G_{i}}{d x}\left(l-a_{i}\right)=0, \quad(i=1, \ldots, m),
$$

then function $V(x)$, which satisfies representation (11), is the generalized solution of (7), and satisfies the boundary conditions (8).

Indeed, for the function $V(x)$, which satisfies (11), the satisfaction of the boundary conditions (8) follows immediately from the boundary conditions (13) for the functions $G_{i}(x),(i=1, \ldots, m)$.

Similar corollaries may be formulated for the function $V(x)$, which satisfies both representation (11) and the boundary conditions (9) or (10). In case of boundary conditions (9) or $(10)$, functions $G_{i}(x),(i=1, \ldots, m)$ shall satisfy, respectively, the following boundary conditions:

$$
G_{i}\left(-a_{i}\right)=0, \quad G_{i}\left(l-a_{i}\right)=0, \quad \frac{d G_{i}}{d x}\left(-a_{i}\right)=0, \quad \frac{d^{2} G_{i}}{d x^{2}}\left(l-a_{i}\right)=0, \quad(i=1, \ldots, m)
$$

and

$$
G_{i}\left(-a_{i}\right)=0, \quad \frac{d G_{i}}{d x}\left(-a_{i}\right)=0, \quad \frac{d^{2} G_{i}}{d x^{2}}\left(l-a_{i}\right)=0, \frac{d^{3} G_{i}}{d x^{3}}\left(l-a_{i}\right)=0 . \quad(i=1, \ldots, m) .
$$

\section{On Finding the Eigenvalues}

For the purpose of funding the functions $G_{1}(x), G_{2}(x), \ldots, G_{m}(x)$, which enter (11), we have $m$ boundary value problems for the equation

$$
\lambda^{2} k G(x)+b \frac{d^{4} G(x)}{d x^{4}}=\delta(x)
$$

with the boundary conditions (15), (16) or (17) depending on the problem statement.

The general solution $G(x)$ of (18) can be found in the form of the sum of the general solution $G_{0}(x)$ of the homogeneous equation

$$
\lambda^{2} k G(x)+b \frac{d^{4} G(x)}{d x^{4}}=0
$$

and some particular generalized solution $\widetilde{G}(x)$ of the non-homogeneous equation (18), i.e.

$$
G(x)=G_{0}(x)+\widetilde{G}(x) .
$$

The general solution $G_{0}(x)$ of the homogeneous equation (19) may be written in the form

$$
G_{0}(x)=c_{1} e^{k_{1} x}+c_{2} e^{k_{2} x}+c_{3} e^{k_{3} x}+c_{4} e^{k_{4} x},
$$

where $c_{1}, c_{2}, c_{3}, c_{4}$ are arbitrary constants; $k_{1}, k_{2}, k_{3}, k_{4}$ are the roots of the characteristic equation, which are defined as follows:

$$
k_{1}=\left(\frac{\sqrt{2}}{2}+i \frac{\sqrt{2}}{2}\right) m, \quad k_{2}=\left(\frac{\sqrt{2}}{2}-i \frac{\sqrt{2}}{2}\right) m,
$$




$$
k_{3}=\left(-\frac{\sqrt{2}}{2}-i \frac{\sqrt{2}}{2}\right) m, \quad k_{4}=\left(-\frac{\sqrt{2}}{2}+i \frac{\sqrt{2}}{2}\right) m .
$$

Here $m^{4}=\frac{\lambda^{2} k}{b}$. Note that the expression of the generalized solution $G_{0}(x)$ defines the general complex solution of equation (19).

To the end of obtaining a particular generalized solution $\widetilde{G}(x)$ of non-homogeneous equation (18) let us use the following statement, which represents a corollary of the theorem on the fundamental solution for the linear differential equation [19].

Proposition 1. If the function $f(x)$ represents a solution of the homogeneous equation (19), which satisfies the following conditions

$$
f(0)=f^{I}(0)=f^{I I}(0)=0, \quad f^{I I I}(0)=\frac{1}{b},
$$

then function $G(x)=\theta(x) f(x)$, where $\theta(x)$ is the Heaviside function

$$
\theta(x)= \begin{cases}1, & x>0 \\ 0, & x<0\end{cases}
$$

satisfies equation (18) in the generalized sense.

Note, the solution of the homogeneous equation (19), which satisfies conditions (21) can be found in the following form

$$
f(x)=\alpha_{1}\left(e^{k_{2} x}-e^{k_{1} x}\right)+\alpha_{2}\left(e^{k_{3} x}-e^{k_{1} x}\right)+\alpha_{3}\left(e^{k_{4} x}-e^{k_{1} x}\right),
$$

where

$$
\begin{gathered}
\alpha_{1}=\frac{1}{b\left(k_{2}-k_{1}\right)\left(k_{2}-k_{3}\right)\left(k_{2}-k_{4}\right)}, \quad \alpha_{2}=\frac{1}{b\left(k_{3}-k_{1}\right)\left(k_{3}-k_{2}\right)\left(k_{3}-k_{4}\right)}, \\
\alpha_{3}=\frac{1}{b\left(k_{4}-k_{1}\right)\left(k_{4}-k_{2}\right)\left(k_{4}-k_{3}\right)} .
\end{gathered}
$$

Therefore, the function

$$
G(x)=\theta(x)\left(\alpha_{1}\left(e^{k_{2} x}-e^{k_{1} x}\right)+\alpha_{2}\left(e^{k_{3} x}-e^{k_{1} x}\right)+\alpha_{3}\left(e^{k_{4} x}-e^{k_{1} x}\right)\right)
$$

represents a particular generalized solution of the non-homogeneous equation (18).

To the end of finding generalized solutions $G_{1}(x), G_{2}(x), \ldots, G_{m}(x)$ of $(12)$ satisfying the boundary conditions given according to the problem statement, let us define arbitrary constants $c_{1}, c_{2}, c_{3}, c_{4}$, in the general solution presuming satisfaction of the respective boundary conditions.

Further, by sequential substituting the following values to the variables $x=a_{1}, x=a_{2}$, $\ldots, x=a_{m}$ in (11), we obtain the following system of linear algebraic equations with respect to $V\left(a_{1}\right), V\left(a_{2}\right), \ldots, V\left(a_{m}\right)$

$$
\begin{aligned}
\left.\left(1+G_{j}(0)\left(q_{j}+\lambda p_{j}\right)\right) V\left(a_{j}\right)+\sum_{\substack{i=1, i \neq j}}^{m} G_{i}\left(a_{j}-a_{i}\right)\left(q_{i}+\lambda p_{i}\right) V\left(a_{i}\right)\right)= & \\
& =\sum_{i=1}^{m} G_{i}\left(a_{j}-a_{i}\right) d^{i T}\left(q_{i}+\lambda p_{i}\right) Z, \quad(j=1, \ldots, m) .
\end{aligned}
$$



form:

Having applied matrix denotations, system (22) may be rewritten in the following

$$
N Z-M \bar{V}=0
$$

where $M$ is the $m \times m$ matrix

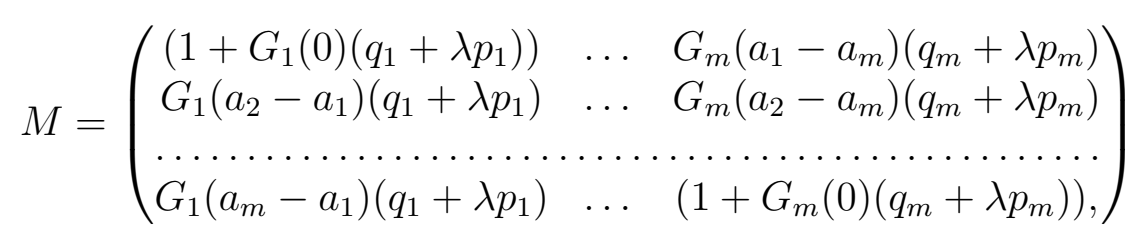

$N$ is the $m \times n$ matrix

$$
N=\left(\begin{array}{ccc}
\sum_{i=1}^{m} G_{i}\left(a_{1}-a_{i}\right)\left(q_{i}+\lambda p_{i}\right) d_{1}^{i} & \ldots & \sum_{i=1}^{m} G_{i}\left(a_{1}-a_{i}\right)\left(q_{i}+\lambda p_{i}\right) d_{n}^{i} \\
\sum_{i=1}^{m} G_{i}\left(a_{2}-a_{i}\right)\left(q_{i}+\lambda p_{i}\right) d_{1}^{i} & \ldots & \sum_{i=1}^{m} G_{i}\left(a_{2}-a_{i}\right)\left(q_{i}+\lambda p_{i}\right) d_{n}^{i} \\
\ldots \ldots \ldots \ldots \ldots \ldots \ldots \ldots \ldots \ldots \ldots \ldots \ldots \ldots \ldots \ldots \ldots \ldots \ldots \ldots \ldots \ldots \ldots \ldots \ldots \ldots \ldots \\
\sum_{i=1}^{m} G_{i}\left(a_{m}-a_{i}\right)\left(q_{i}+\lambda p_{i}\right) d_{1}^{i} & \ldots & \sum_{i=1}^{m} G_{i}\left(a_{m}-a_{i}\right)\left(q_{i}+\lambda p_{i}\right) d_{n}^{i}
\end{array}\right)
$$

Having joined (23) and (6), we obtain a system of linear homogeneous algebraic equations with respect to the vector of amplitudes $Z$ and $\bar{V}$ :

$$
\left\{\begin{array}{l}
\lambda^{2} A+C_{1}+C_{2} D+\lambda\left(B_{1}+B_{2} D\right) Z-\left(C_{2}+\lambda B_{2}\right) \bar{V}=0 \\
N Z-M \bar{V}=0
\end{array}\right.
$$

System (24) has nonzero solutions when its determinant is zero. Having equated the determinant of (24) to zero, we obtain the equation needed for finding of the eigenvalues of the boundary value problem

$$
\operatorname{det}\left(\begin{array}{cc}
\lambda^{2} A+C_{1}+C_{2} D+\lambda\left(B_{1}+B_{2} D\right) & -\left(C_{2}+\lambda B_{2}\right) \\
N & -M
\end{array}\right)=0 .
$$

\section{Example. The Comparative Analysis}

Consider a console rod with three rigid bodies installed (mounted) on springs. The respective computational model is given in Figure. The rod's left end if stiffly fixed, while the right end is not fixed.

Rigid bodies having masses, respectively, $m_{1}, m_{2}, m_{3}$, are mounted on the springs having the stiffness coefficients, respectively, $c_{1}, c_{2}, c_{3}$ at the distances $a_{1}, a_{2}, a_{3}$ from the rod's left end and execute translational motions (displacements) $z_{1}(t), z_{2}(t), z_{3}(t)$ in the direction of the axes $O_{1} z_{1}, O_{2} z_{2}, O_{3} z_{3}$. In the resent case, the points $O_{1}, O_{2}, O_{3}$ coincide with the equilibrium positions for these bodies. Displacements of the points of this rod may be described by function $u(x, t)$. 


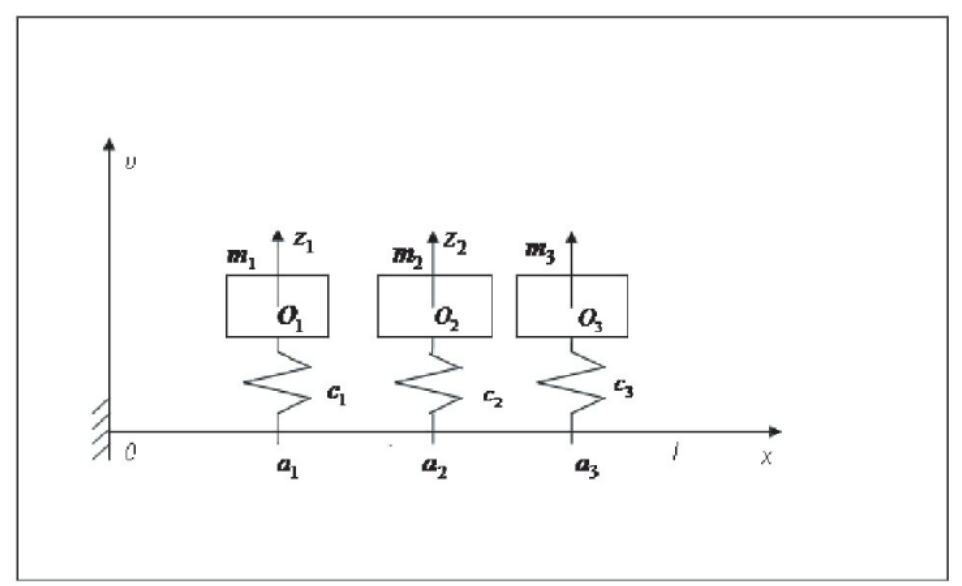

The computational scheme for the system represented by the console rod with three oscillators presuming damping

The hybrid system of differential equations describing motion of the scrutinized system, which has been obtained on the basis of the Hamilton principle, writes as follows:

$$
\left\{\begin{array}{l}
m_{1} \ddot{z}_{1}+b_{1}\left(\dot{z}_{1}-\frac{\partial u}{\partial t}\left(a_{1}, t\right)\right)+c_{1}\left(z_{1}-u\left(a_{1}, t\right)\right)=0, \\
m_{2} \ddot{z}_{2}+b_{2}\left(\dot{z}_{2}-\frac{\partial u}{\partial t}\left(a_{2}, t\right)\right)+c_{2}\left(z_{2}-u\left(a_{2}, t\right)\right)=0, \\
m_{3} \ddot{z}_{3}+b_{3}\left(\dot{z}_{3}-\frac{\partial u}{\partial t}\left(a_{3}, t\right)\right)+c_{3}\left(z_{3}-u\left(a_{3}, t\right)\right)=0, \\
\rho F \frac{\partial^{2} u}{\partial t^{2}}+E J \frac{\partial^{4} u}{\partial x^{4}}=\left(c_{1}\left(z_{1}-u(x, t)\right)+b_{1}\left(\dot{z}_{1}-\frac{\partial u}{\partial t}(x, t)\right) \delta\left(x-a_{1}\right)+\right. \\
+\left(c_{2}\left(z_{2}-u(x, t)\right)+b_{2}\left(\dot{z}_{2}-\frac{\partial u}{\partial t}(x, t)\right) \delta\left(x-a_{2}\right)+\right. \\
+\left(c_{3}\left(z_{3}-u(x, t)\right)+b_{3}\left(\dot{z}_{3}-\frac{\partial u}{\partial t}(x, t)\right) \delta\left(x-a_{3}\right) .\right.
\end{array}\right.
$$

Here $\rho$ is the volume density of the rod's material; $F$ is the area of the rod's crosssection; $E, J$ are, respectively, the first-kind elastic modulus for the rod's material, and the inertia moment for the rod's cross-section area with respect to the axis passing through the cross-sectional gravity center, which is perpendicular to the plane of the rod's bending vibrations; $b$ is the viscous friction coefficient characterising the spring's material. The boundary conditions (4) are imposed on function $u(x, t)$.

The hybrid system of differential equations (25) represents a particular case of the proposed generalized mathematical model (1).

For the purpose of conducting the comparative analysis of the proposed approach we have used the data of the model and the computations described in [18].

$l=1 m$ is the length of the console rod;

$\rho F=0,675 \mathrm{~kg} / \mathrm{m}$ is the mass of the rod's unit length;

$J=5,20833 \cdot 10^{-10} \mathrm{~m}^{4}$ is the inertia moment of the cross-sectional area with respect to the neutral axis passing through the cross-sectional gravity center and perpendicular to the plane of the rod's vibrations;

$a_{1}=0,1 m, a_{2}=0,5 m, a_{3}=0,9 m$ are the points at which the oscillators are mounted (fixed);

$b_{1}=0,1 N s / m, b_{2}=0,1 N s / m, b_{3}=0,1 N s / m$ are the viscous friction coefficients; 
$c_{1}=0,1 N / m, c_{2}=0,1 N / m, c_{3}=0,1 N / m$ are the stiffness coefficients of the springs in the oscillators;

$E=7 \cdot 10^{1} 0 \mathrm{~N} / \mathrm{m}^{2}$ is the Young's (elongation) modulus.

The comparison of the data of computations conducted on the basis of the approach proposed in the present paper for the first two eigenvalues

$$
\lambda_{1}=-0,255+25,839 i, \quad \lambda_{2}=-0,235+161,938 i,
$$

and the data of computations of the eigenvalues given in paper [18]:

$$
\omega_{1}=-0,255+25,829, \quad \omega_{2}=-0,235+161,941,
$$

gives evidence of good coincidence of the results.

Acknowledgements. The work has been financially supported by the Russian Foundation for Basic Research, grant 15-08-00973.

\section{References}

1. Barguev S.G., Mizhidon A.D. The Definion of an Own Frequency of Trivial Mechanical System on Elastic Foundation. Vestnik Buryatskogo Gosudarstvennogo Universiteta. Matematika, Informatika [Bulletin of Buryat State University. Mathematics, Informatics], 2009, no. 9, pp. 58-63. (in Russian)

2. Mizhidon A.D., Barguev S.G., Lebedeva N.V. To Research of a Vibroprotection System with Elastic Basement. Modern Technologies. System Analysis. Modeling, 2009, no. 2 (22), pp. 13-20. (in Russian)

3. Mizhidon A.D., Barguev S.G. About Own Fluctuations of the Cascade Type Mechanical System Established on the Elastic Core. Vestnik Vostochno-Sibirskogo Gosudarstvennogo Universiteta Tehnologij i Upravlenija [Bulletin of East Siberia State University of Technology and Management], 2010, no. 1, pp. 26-32. (in Russian)

4. Barguev S.G., Eltoshkina E.V., Mizhidon A.D., Tsytsyrenova M.Zh. Investigation of the Possibility of Fluctuations Damping of $n$ Masses Loid on an Elastic Rod. Modern Technologies. System Analysis. Modeling, 2010, no. 4 (28), pp. 78-84. (in Russian)

5. Barguev S.G., Mizhidon A.D. Solution of the Initial Boundary Problem Vibrations of the Oscillator on the Elastic Rod. Vestnik Buryatskogo Gosudarstvennogo Universiteta. Matematika, Informatika [Bulletin of Buryat State University. Mathematics, Informatics], 2012, no. 2, pp. 63-68. (in Russian)

6. Mizhidon A.D., Barguev S.G. Boundary Value Problem for One Hybrid System of Differential Equations. Vestnik Buryatskogo Gosudarstvennogo Universiteta. Matematika, Informatika [Bulletin of Buryat State University. Mathematics, Informatics], 2013, no. 9, pp. 130-137. (in Russian)

7. Mizhidon A.D., Tsytsyrenova M.Zh. A Generalized Mathematical Model of Rigid Bodies Mounted on Elastic Rod. Vestnik Vostochno-Sibirskogo Gosudarstvennogo Universiteta Tehnologij i Upravlenija [Bulletin of East Siberia State University of Technology and Management], 2013, no. 6, pp. 5-12. (in Russian)

8. Mizhidon A.D., Dabaeva M.Zh. Accounting for Elastic Ties Damping Properties in Generalized Mathematical Model of Solids System Mounted on Elastic Rod. Vestnik Vostochno-Sibirskogo Gosudarstvennogo Universiteta Tehnologij i Upravlenija [Bulletin of East Siberia State University of Technology and Management], 2015, no. 2, pp. 10-17. (in Russian) 
9. Cha P.D. Free Vibration of a Uniform Beam with Multiple Elastically Mounted Two-degreeof-freedom Systems. Journal of Sound and Vibration, 2007, vol. 307, issues 1-2, pp. 386-392. DOI: $10.1016 /$ j.jsv.2007.06.063

10. Wu J.-J., Whittaker A.R. The Natural Frequencies and Mode Shapes of a Uniform Cantilever Beam with Multiple Two-DOF Spring-Mass Systems. Journal of Sound and Vibration, 1999, vol. 227, issue 2, pp. 361-381. DOI: 10.1006/jsvi.1999.2324

11. Wu J.-S., Chou H.-M. A New Approach for Determining the Natural Frequencies and Mode Shapes of a Uniform Beam Carrying Any Number of Spring Masses. Journal of Sound and Vibration, 1999, vol. 220, issue 3, pp. 451-468. DOI: 10.1006/jsvi.1998.1958

12. Wu J.-S. Alternative Approach for Free Vibration of Beams Carrying a Number of TwoDegree of Freedom Spring-Mass Systems. Journal of Structural Engineering, 2002, vol. 128, issue 12, pp. 1604-1616. DOI: 10.1061/(ASCE)0733-9445(2002)128:12(1604)

13. Naguleswaran S. Transverse Vibration of an Euler - Bernoulli Uniform Beam Carrying Several Particles. International Journal of Mechanical Sciences, 2002, vol. 44, issue 12, pp. 2463-2478. DOI: 10.1016/S0020-7403(02)00182-0

14. Naguleswaran S. Transverse Vibration of an Euler - Bernoulli Uniform Beam on up a Five Resilient Supports Including End. Journal of Sound and Vibration, 2003, vol. 261, issue 2, pp. 372-384. DOI: $10.1016 / \mathrm{S} 0022-460 \mathrm{X}(02) 01238-5$

15. Kukla S., Posiadala B. Free Vibrations of Beams with Elastically Mounted Masses. Journal of Sound and Vibration, 1994, vol. 175, issue 4, pp. 557-564. DOI: 10.1006/jsvi.1994.1345

16. Su H., Banerjee J.R. Exact Natural Frequencies of Structures Consisting of Two Part BeamMass Systems. Structural Engineering and Mechanics, 2005, vol. 19, issue 5, pp. 551-566. DOI: $10.12989 /$ sem.2005.19.5.551

17. Lin H.-Y., Tsai Y.-C. Free Vibration Analysis of a Uniform Multi-Span Beam Carrying Multiple Spring-Mass Systems. Journal of Sound and Vibration, 2007, vol. 302, issue 3, pp. 442-456. DOI: $10.1016 /$ j.jsv.2006.06.080

18. Wu J.-S., Chen D.-W. Dynamic Analysis of Uniform Cantilever Beam Carrying a Number of Elastically Mounted Point Masses with Dampers. Journal of Sound and Vibration, 2000, vol. 229, issue 3, pp. 549-578. DOI: 10.1006/jsvi.1999.2504

19. Vladimirov V.S. Obobshchennye funktsii $v$ matematicheskoy fizike [Generalized Solutions in Mathematical Physics]. Moscow, Nauka, 1976. 280 p.

Received January 18, 2016

УДК 519.62, 519.63

DOI: $10.14529 / \mathrm{mmp} 170102$

\section{МОДЕЛИРОВАНИЕ МЕХАНИЧЕСКИХ СИСТЕМ ПОСРЕДСТВОМ ОБЪЕДИНЕНИЯ УРАВНЕНИЙ С СОСРЕДОТОЧЕННЫМИ И РАСПРЕДЕЛЕННЫМИ ПАРАМЕТРАМИ}

\section{А.Д. Мижсидон}

В данной статье рассматривается краевая задача для гибридной системы дифференциальных уравнений, представляющей собой обобщенную математическую модель 
систем взаимосвязанных твердых тел, прикрепленных упруго демпфирующими связями к стержню. Под гибридными системами дифференциальных уравнений понимается система дифференциальных уравнений, состоящая из обыкновенных дифференциальных уравнений и уравнений в частных производных. В качестве теоретических основ исследования краевой задачи для гибридной системы дифференциальных уравнений предлагается метод нахождения собственных значений краевой задачи. Сравнительный анализ численных расчетов, проведенных предложенным методом с расчетами проведенными другими способами, известными из литературы, показал достоверность и универсальность предлагаемого подхода.

Ключевые слова: краевая задача; гибридная система дифференциальных уравнений; собственные значения.

\section{Литература}

1. Баргуев, С.Г. Определение собственных частот простейшей механической системы на упругом основании / С.Г. Баргуев, А.Д. Мижидон // Вестник Бурятского государственного университета. Математика, информатика. - 2009. - № 9. - С. 58-63.

2. Мижидон, А.Д. К исследованию виброзащитной системы с упругим основанием / А.Д. Мижидон, С.Г. Баргуев, Н.В. Лебедева // Современные технологии. Системный анализ. Моделирование. - 2009. - № 2 (22). - С. 13-20.

3. Мижидон, А.Д. О собственных колебаниях механической системы каскадного типа, установленной на упругом стержне / А.Д. Мижидон, С.Г. Баргуев // Вестник ВосточноСибирского государственного университета технологий и управления. -2010 . - № $1 .-$ C. $26-32$.

4. Баргуев, С.Г. Исследование возможности гашения $\mathrm{n}$ масс, установленных на упругом стержне / С.Г. Баргуев, Е.В. Елтошкина, А.Д. Мижидон, М.Ж. Цыцыренова // Современные технологии. Системный анализ. Моделирование. - 2010. - № 4 (28). - С. 78-84.

5. Баргуев, С.Г. Решение начально-краевой задачи о колебаниях осциллятора на упругом стержне / С.Г. Баргуев, А.Д. Мижидон // Вестник Бурятского государственного университета. Математика, информатика. - 2012. - № 2. - С. 63-68.

6. Мижидон, А.Д. Краевая задача для одной гибридной системы дифференциальных уравнений / А.Д. Мижидон, С.Г. Баргуев // Вестник Бурятского государственного университета. Математика, информатика. - 2013. - № 9. - С. 130-137.

7. Мижидон, А.Д. Обобщенная математическая модель системы твердых тел, установленных на упругом стержне / А.Д. Мижидон, М.Ж. Цыцыренова // Вестник ВосточноСибирского государственного университета технологий и управления. - 2013. - № 6. C. $5-12$.

8. Мижидон, А.Д. Математическое моделирование, учет демпфирующих свойств упругих связей в обобщенной математической модели системы твердых тел, установленных на упругом стержне / А.Д. Мижидон, М.Ж. Дабаева // Вестник ВСГУТУ. - 2015. - № 2. C. $10-17$.

9. Cha, P.D. Free Vibration of a Uniform Beam with Multiple Elastically Mounted Two-Degreeof-Freedom Systems / P.D. Cha // Journal of Sound and Vibration. - 2007. - V. 7, № 1-2. P. 386-392.

10. Wu, J.-J. The Natural Frequencies and Mode Shapes of a Uniform Cantilever Beam with Multiple Two-DOF Spring-Mass Systems / J.-J. Wu, A.R. Whittaker // Journal of Sound and Vibration. - 1999. - V. 227, № 2. - P. 361-381.

11. Wu, J.-S. A New Approach for Determining the Natural Frequencies and Mode Shapes of a Uniform Beam Carrying any Number of Spring Masses / J.-S. Wu, H.-M. Chou // Journal of Sound and Vibration. - 1999. - V. 220, № 3. - P. 451-468. 
12. Wu, J.-S. Alternative Approach for Free Vibration of Beams Carrying a Number of TwoDegree of Freedom Spring-Mass Systems / J.-S. Wu // Journal of Structural Engineering ASCE. - 2002. - V. 128, № 12. - P. 1604-1616.

13. Naguleswaran, S. Transverse Vibration of an Euler - Bernoulli Uniform Beam Carrying Several Particles / S. Naguleswaran // International Journal of Mechanical Sciences. - 2002. V. 44, № 12. - P. 2463-2478.

14. Naguleswaran, S. Transverse Vibration of an Euler - Bernoulli Uniform Beam on up a Five Resilient Supports Including End / S. Naguleswaran // Journal of Sound and Vibration. 2003. - V. 261, № 2. - P. 372-384.

15. Kukla, S. Free Vibrations of Beams with Elastically Mounted Masses / S. Kukla, B. Posiadala // Journal of Sound and Vibration. - 1994. - V. 175, № 4. - P. 557-564.

16. Su, H. Exact Natural Frequencies of Structures Consisting of Two Part Beam-Mass Systems / H. Su, J.R. Banerjee // Structural Engineering and Mechanics. - 2005. - V. 19, № 5. P. 551-566.

17. Lin, H.-Y. Free Vibration Analysis of a Uniform Multi-Span Beam Carrying Multiple SpringMass Systems / H.-Y. Lin, Y.-C. Tsai // Journal of Sound and Vibration. - 2007. - V. 302, № 3. - P. $442-456$.

18. Wu, J.-S. Dynamic Analysis of Uniform Cantilever Beam Carrying a Number of Elastically Mounted Point Masses with Dampers / J.-S. Wu, D.-W. Chen // Journal of Sound and Vibration. - 2000. - V. 229, № 3. - P. 549-578.

19. Владимиров, В.С. Обобщенные функции в математической физике / В.С. Владимиров. М.: Наука, 1976.

Арсалан Дугарович Мижидон, доктор технических наук, профессор, кафедра «Прикладная математика», Восточно-Сибирский государственный университет технологий и управления (г. Улан-Удэ, Российская Федерация), miarsdu@mail.ru.

Поступила в редакиию 18 января 2016 г. 